\title{
Pengaruh Pengusangan Cepat Secara Fisik Terhadap Penurunan Viabilitas Tetua Benih Padi Hibrida (Oryza sativa L.)
}

\author{
Effect of Physical Rapid Aging Method \\ for Decreasing of Seed Viability \\ on Parental Lines of Hybrid Rice Seed (Oryza sativa L.)
}

\author{
Nelly Fridayanti \\ Program Studi Agroekoteknologi, Fakultas Pertanian, Universitas Malikussaleh \\ Kampus Cot Teungku Nie, Reuleut, Muara Batu, Aceh Utara 24355, Indonesia \\ Email:
}

Diterima 5 Juli 2014; Dipublikasi 1 September 2014

\begin{abstract}
Abstrak
Tujuan penelitian ini adalah untuk mengetahui metode pengsangan cepat dalam penurunan viabilitas benih. Penurunan viabilitas benih termasuk persentase perkecambahan, indeks vigor, potensi pertumbuhan maksimum dan daya simpan benih. Viabilitas benih diuji dengan metode Antara Paper (BP) sedangkan daya simpan benih dilakukan setelah Rapid agent Metode (RAM) pada suhu 410C dan RH> $90 \%$ selama 72 jam. Hasil penelitian menunjukkan bahwa pengusangan cepat secara fisik dapat menurunkan vaibilitas benih.
\end{abstract}

Kata kunci: pengusangan cepat, viabilitas, IR58025A, IR62829A

\begin{abstract}
This research aims to study the rapid aging method on decreasing of seed viability. Decreasing seed viability including germination percentage, vigor index, maximum growth potential and seed storability. Seed viability was tested using Between Paper (BP) method whereas seed storability was done following Rapid Aging Method (RAM) with 410C and RH > 90\% treatments for 72 hours. The results showed that the rapid aging physically will decrease seed viability.
\end{abstract}

Keywords : rapid aging, viability, IR58025A, IR62829A

\section{Pendahuluan}

Daya simpan benih adalah kemampuan benih untuk mempertahankan viabilitasnya selama di penyimpanan yang dinyatakan dalam satuan waktu. Pendugaan daya simpan benih dapat dideteksi secara simulatif dengan pengusangan cepat secara fisik yaitu dengan suhu dan kelembaban tinggi.

Faktor-faktor yang dapat mempengaruhi daya simpan benih adalah faktor genetik (innate factor), faktor lapangan mulai dari pertumbuhan tanaman induk, pembentukan benih, pemanenan, pengolahan, sampai benih siap disimpan (induced factor) dan kondisi penyimpanan (enforced factor) (Sadjad et al. 1984). Faktor innate sangat ditentukan oleh gen yang diwariskan oleh tetuanya. Sebagai contoh pengaruh faktor genetik menyebabkan perbedaan komposisi kimia benih antar varietas berbeda ukuran, ketebalan kulit dan warna kulit.

Faktor induced meliputi keadaan tanaman induk sewaktu di lapang, pembentukan benih, cara panen, cara pengolahan dan lamanya periode konservasi yang dilewati benih tersebut. Kondisi tanaman induk di lapang dipengaruhi oleh tingkat kesuburan lahan produksi, keadaan curah hujan dan pengaruh serangan hama dan penyakit.

Faktor enforced adalah faktor lingkungan simpan yang mencakup suhu, kelembaban nisbi dan biosfir ruang simpan. Pada kelembaban yang tinggi benih akan mengalami kemunduran secara cepat, begitu juga pada suhu ruang simpan yang tinggi. Kemunduran benih dalam ruang simpan dapat diperlambat jika suhu dan kelembaban ruang simpan diturunkan, bahkan pada suhu di bawah $0^{\circ} \mathrm{C}$ benih masih dapat hidup asalkan 
kadar air benih yang disimpan dalam keadaan optimum.

Pengusangan cepat adalah metode yang dapat digunakan untuk memperoleh beberapa tingkat viabilitas benih. Metode ini ditemukan pertama kali oleh Delouche (1971) dengan menggunakan perlakuan fisik yaitu suhu 41 oC dan RH sekitar $100 \%$ selama tiga sampai empat hari dan dikembangkan oleh Baskin dan McDonald (Copeland dan McDonald, 2001). Metode tersebut digunakan sebagai metode standar untuk pengujian vigor benih kedelai (ISTA, 2007). Sadjad (1994) menemukan metode pengusangan cepat menggunakan senyawa kimiawi yaitu etanol. Pengusangan cepat mengakibatkan rusaknya dinding sel benih kacang polong yang menjadikan banyak elektrolit yang keluar sehingga daya hantar listrik (DHL) meningkat dan terjadinya aberasi kromosom oleh reduksi bebas.

Menurut (Sadjad, 1980) ada dua metode untuk menduga daya simpan benih secara tepat yaitu secara fisik dan kimiawi. Metode pengusangan baik secara fisik dan kimiawi merupakan salah satu produk teknologi modern yang telah digunakan dalam bidang perbenihan, terutama untuk menduga daya simpan benih dalam waktu relatif singkat.

Di dalam pengusangan cepat secara fisik benih diberi perlakuan temperatur tinggi (40 $50^{\circ} \mathrm{C}$ ) dan kelembaban tinggi (> 90\%) yang memberikan gambaran kemampuan benih untuk disimpan dalam kurun waktu tertentu. Lot benih yang bervigor tinggi akan mengalami sedikit kemunduran setelah diberi perlakuan pengusangan, sedangkan lot benih yang bervigor rendah akan mengalami kemunduran yang sangat nyata setelah pengusangan (Blance \& Elam, 1989). Periode pengusangan yang digunakan untuk benih padi adalah dengan suhu 41 0C dengan kelembaban nisbi $>90 \%$ selama 72 jam (Rice Seed Testing Services. http://www.mwseed.com/rice.htm on line $30 \mathrm{Juli}$ 2014).

Umumnya pengusangan ditujukan sebagai metode untuk menguji daya simpan benih, namun menurut (Copeland \& McDonald, 1995), pengusangan dapat pula digunakan sebagai metode uji vigor.

Tujuan dari penelitian ini adalah untuk mengetahui seberapa besar pengaruh pengusangan cepat secara fisik terhadap penurunan viabilitas tetua benih padi hibrida.

\section{Metode Penelitian}

Penelitian dilaksanakan di Laboratorium Ilmu dan Teknologi Benih Fakultas Pertanian, Institut Pertanian Bogor. Bahan-bahan yang digunakan adalah varietas tetua padi hibrida yang terdiri dari restorer/tetua jantan MTU9992, IR65515, kertas merang, kantong plastik, kertas alumunium, kertas tissu dan kertas label. Alatalat yang digunakan adalah alat pengepres substrat kertas merang IPB 75, germinator IPB 73-2B, timbangan digital, oven, inkubator, desikator dan alat-alat tulis.

Viabilitas benih diuji dengan menggunakan metode UKDdp (Uji Kertas Digulung didirikan dalam plastik). Peubah yang diamati terdiri dari : daya berkecambah, indeks vigor, dan potensi tumbuh maksimum. Pendugaan daya simpan benih dilakukan secara simulatif dengan metode pengusangan cepat pada suhu tinggi $( \pm$ $41^{\circ} \mathrm{C}$ ) dan kelembaban tinggi (> 90\%) selama 72 jam.

\section{Indeks Vigor (IV, \%)}

Indeks vigor adalah vigor kecepatan tumbuh yang dinyatakan dalam persen. Indeks vigor dihitung berdasarkan persentase kecambah normal terhadap total benih yang dikecambahkan pada hitungan pertama (Copeland \& McDonald, 1995).

$$
\mathrm{IV}=\frac{\sum \text { kecambah normal hitungan I }}{\sum \text { benih yang ditanam }} \times 100 \%
$$

\section{Daya Berkecambah (DB, \%)}

Daya berkecambah dihitung berdasarkan persentase kecambah normal pada akhir pengamatan terhadap total benih yang dikecambahkan. Pengamatan dilakukan pada hari ke-5 (hitungan 1) dan ke-7 (hitungan 2) (Sadjad 1993) dengan rumus :

$$
\mathrm{DB}=\frac{\sum \text { kecambah normal hitungan } \mathrm{I} \& 2}{\sum \text { benih yang ditanam }} \times 100 \%
$$

\section{Potensi Tumbuh Maksimum (PTM, \%)}

Viabilitas total adalah semua benih yang hidup termasuk yang dorman. Parameter viabilitas total diukur berdasarkan persentase benih yang hidup dengan tolok ukur potensi tumbuh maksimum. Potensi tumbuh maksimum dihitung berdasarkan persentase benih yang 
mampu menjadi kecambah normal maupun abnormal pada pengamatan hari terakhir (hari ke 7) dibagi dengan jumlah benih yang ditanam.

$$
\mathrm{PTM}=\frac{\sum \text { benih yang mampu berkecambah }}{\sum \text { benih yang ditanam }} \times 100 \%
$$

\section{Daya Simpan Benih}

Devigorasi secara fisik digunakan untuk menganalisis vigor absolut yang menstimulasi daya simpan benih. Benih yang tahan terhadap kondisi deraan lingkungan simpan suboptimum dan tahan untuk disimpan dalam kondisi yang tidak ideal. Daya simpan benih diamati secara simulatif melalui perlakuan pengusangan cepat secara fisik dengan menggunakan inkubator pada suhu $41^{\circ} \mathrm{C}$ dan kelembaban tinggi $>90 \%$ selama 72 jam. Setelah dilakukan pengusangan benih dikecambahkan pada media kertas stensil lembab dengan metode UKDdp. Kertas stensil yang digunakan sebanyak tiga lembar. Jumlah benih dikecambahkan sebanyak 50 butir tiap gulungan kertas dengan tiga ulangan. Benih dikecambahkan dalam APB IPB 73-2B. Tolok ukur terhadap daya simpan adalah daya berkecambah, indeks vigor dan potensi tumbuh maksimum.

\section{Analisis Data}

Untuk mengetahui pengaruh faktor yang diuji dilakukan analisis ragam. Apabila dalam analisis ragam terdapat pengaruh yang nyata pada taraf 5\%, maka dilakukan uji lanjut terhadap nilai rata-rata perlakuan untuk mengetahui perbedaan antar perlakuan dengan menggunakan DMRT (Stell \& Torrie, 1993).

\section{Hasil dan Pembahasan}

\section{Viabilitas Benih pada Saat Panen}

Vigor awal benih dipengaruhi oleh faktor innate dan induced (Sadjad 1984, diacu dalam Ilyas 1986). Faktor innate disebabkan oleh perbedaan spesies/varietas (genetik) sedangkan faktor induced dipengaruhi oleh kondisi tanaman induk selama di lapang, proses pemanenan dan pasca panen. Indeks vigor adalah tolok ukur vigor kekuatan tumbuh benih, daya berkecambah adalah tolok ukur viabilitas potensial dan potensi tumbuh maksimum merupakan tolok ukur viabilitas total.
Tabel 1. Mutu Fisiologis Varietas Tetua Padi Hibrida pada Saat Panen

\begin{tabular}{lccc}
\hline Perlakuan & IV (\%) & DB (\%) & $\begin{array}{c}\text { PTM } \\
(\%)\end{array}$ \\
\hline Varietas & & & \\
MTU9992 & $28,3 \mathrm{~b}$ & $85,2 \mathrm{~b}$ & $96,4 \mathrm{~b}$ \\
IR65515 & $24,4 \mathrm{~b}$ & $86,4 \mathrm{~b}$ & $96,4 \mathrm{~b}$ \\
IR58025A & $39,5 \mathrm{a}$ & $89,4 \mathrm{a}$ & $97,7 \mathrm{a}$ \\
IR62829A & $44,1 \mathrm{a}$ & $89,3 \mathrm{a}$ & $97,8 \mathrm{a}$ \\
\hline Respon & $* *$ & $* *$ & $* *$ \\
\hline
\end{tabular}

Keterangan: Angka-angka yang diikuti oleh huruf yang sama pada kolom yang sama dan pada perlakuan yang sama tidak berbeda nyata pada DMRT 5\%.** = berbeda sangat nyata; tn = tidak berbeda nyata; IV = Indeks Vigor; DB = Daya Berkecambah; PTM = Potensi Tumbuh Maksimum.

Hasil uji statistik terhadap viabilitas benih pada saat panen menunjukkan bahwa varietas tetua padi hibrida berpengaruh sangat nyata terhadap viabilitas benih. Hal tersebut diduga bahwa setiap varietas mempunyai kemampuan yang berbeda terhadap pengaruh lingkungan.

Selain itu pada Tabel di atas dapat dilihat bahwa rata- rata IV, DB dan PTM varietas IR58025A dan IR62829A lebih tinggi dari pada MTU9992 dan IR65515. Hal ini mengindikasikan bahwa viabilitas padi hibrida yang didapatkan lebih tinggi dari restorer. Menurut (Justice \& Bass 1990, Sadjad 1993) semakin tinggi viabilitas benih maka semakin panjang daya simpannya.

Menurut (Heydecker 1972, diacu dalam Sadjad 1972) menyatakan bahwa ciri dari benih vigor adalah tahan disimpan, dapat berkecambah cepat dan merata, bebas dari penyakit benih, tahan terhadap gangguan mikroorganisme, bibit dapat tumbuh dengan baik di tanah basah maupun kering, bibit secara maksimum dapat memanfaatkan persediaan bahan makanan dalam benih, sehingga tumbuh jaringan-jaringan baru, laju pertumbuhan tinggi, dan menghasilkan produk yang tinggi dalam waktu tertentu.

\section{Daya Simpan Benih}

Daya simpan benih dipengaruhi oleh sifat benih, kondisi lingkungan simpan (faktor enforced) dan perlakuan manusia. Sedangkan daya simpan individu benih dipengaruhi oleh sepuluh faktor sifat dan kondisi yaitu pengaruh genetik (variasi antar spesies dan antar kultivar), pengaruh kondisi sebelum panen (tempat asal 
benih diproduksi dan iklim), pengaruh struktur dan komposisi benih, benih keras, kemasakan benih, ukuran benih, dormansi benih, kadar air benih, kerusakan mekanik dan vigor (Justice \& Bass 1990). Pendugaan daya simpan benih hanya dilakukan terhadap restorer yaitu varietas MTU9992 dan IR65515 karena benih padi hibrida yang dihasilkan tidak banyak sehingga tidak mencukupi untuk dilakukan analisis.

Hasil uji statistik pada Tabel 2 menunjukkan bahwa varietas tetua padi hibrida tidak berpengaruh nyata terhadap pendugaan daya simpan benih melalui uji pengusangan cepat secara fisik terhadap sumua tolok ukur yang diamati. Hasil uji statistik terhadap daya simpan benih menunjukkan bahwa varietas MTU9992 dan IR65515 tidak berpengaruh nyata terhadap daya simpan benih berdasarkan semua tolok ukur yang diamati. Hal ini diduga karena faktor lingkungan tanam khususnya unsur hara Nitrogen, Fosfor dan Kalium sudah cukup bagi pertumbuhan tanaman sehingga benih yang dihasilkan memiliki vigor maksimum.

Daya berkecambah benih setelah pengusangan merupakan peubah yang dapat menggambarkan status viabilitas benih selama penyimpanan. Viabilitas benih yang diusangkan akan berangsur-angsur menurun karena proses kemunduran benih yang dicirikan oleh penurunan kecepatan perkecambahan, keserempakan perkecambahan dan daya berkecambah.

Menurunnya daya berkecambah disebabkan kadar air yang semakin meningkat dan suhu yang tinggi bahkan dapat menjurus pada respirasi anerob, kadar air yang cukup tinggi akan meningkatkan aktivitas biologi dan produksi panas sehingga dapat merusak benih. Kalpana dan Rao (1996) menyatakan bahwa benih yang diusangkan dapat menurunkan kandungan total lipid dan fospolipid sehingga menyebabkan kerusakan membran dan menurunkan nilai perkecambahan. Penurunan lipid dan fospolipid dapat menyebabkan kerusakan membran yang mempengaruhi vigor benih.

Selain itu Menurut Saenong (1986) selama pengusangan cepat terjadi penurunan fosfolipid pada benih kedelai yang berdampak pada rusaknya integritas membran, sehingga semakin lama perlakuan penderaan semakin tinggi DHLnya. Tilebeni dan Golpayageni menjelaskan bawa proses pengusangan cepat berkorelasi dengan penurunan aktivitas peroksidase. Semakin lama pengusangan akan mengakibatkan aktivitas enzim semakin menurun.
Tabel 2. Pengaruh Daya Simpan Benih melalui Uji Pengusangan Cepat Secara Fisik (Indeks Vigor, Daya berkecambah dan Potensi Tumbuh Maksimum.

\begin{tabular}{llll}
\hline Perlakuan & IV (\%) & DB (\%) & PTM (\%) \\
\hline Varietas & & & \\
MTU9992 & 17,6 & 62,4 & 83,5 \\
IR65515 & 17,5 & 61,7 & 83,3 \\
\hline Respons & tn & tn & tn \\
\hline
\end{tabular}

Keterangan: Angka-angka yang diikuti oleh huruf yang sama pada kolom yang sama dan pada perlakuan yang sama tidak berbeda nyata pada DMRT $5 \%$. tn = tidak berbeda nyata; IV = Indeks Vigor; $\mathrm{DB}=$ Daya Berkecambah; $\mathrm{PTM}=$ Potensi Tumbuh Maksimum.

Dengan adanya pengusangan, zat pati yang ada dalam benih secara berangsur-angsur mengalami penurunan, sedangkan asam amino $\mathrm{N}$ mengalami peningkatan. Dengan meningkatnya laju metabolisme selama pengusangan akan mengakibatkan penurunan cadangan makanan dan viabilitas benih serta benih yang abnormal meningkat. Blance dan Elam (1989). Selanjutnya (Copelandc \& Mdonald, 1995) mengemukakan bahwa kemunduran benih merupakan proses mundurnya viabilitas benih yang menimbulkan perubahan menyeluruh dalam benih, baik fisik, fisiologi maupun biokimia yang berakibat menurunnya viabilitas benih. Sedangkan (Byrd, 1983) mengartikan kemunduran benih sebagai semua perubahan yang terjadi di dalam benih yang berakhir pada kematian.

Ketahanan terhadap deraan (pengusangan) juga berhubungan dengan faktor fisik benih, seperti ketebalan dan permeabilitas kulit benih. Kondisi udara yang lembab dan panas, selain mengakibatkan proses metabolisme benih yang berjalan cepat dan berkurangnya energi, juga mendorong pertumbuhan cendawan. Beberapa penelitian tentang pengusangan menjelaskan antara lain Navamaniraj (2008) menjelaskan bahwa penderaan dengan suhu $41^{\circ} \mathrm{C}$ pada benih Bixa orrelana L. yang diskarifikasi mengakibatkan viabilitas menjadi lebih rendah 50\% dibandingkan benih yang tidak diskarifikasi. Penurunan viabilitas benih yang didera secara fisik dapat disebabkan oleh berbagai faktor, misalnya karena terjadinya peningkatan asam lemak bebas pada benih kapas (Gossypium hirsutum L.) (Iqbal et al., 2002). 
Menurut Mavi dan Demir (2010) kerusakan tersebut karena benih adalah mahluk hidup yang apabila disimpan pada kondisi suboptimum (suhu dan RH tinggi) terjadi proses katabolisme yaitu peroksidasi lipid yang mengakibatkan kerusakan membran serta menghasilkan produk sampingan yang beracun sehingga menyebabkan benih mengalami penurunan vigor. Pada kondisi tersebut benih akan melakukan respirasi yang mengakibatkan berkurangnya energi benih untuk tumbuh. Benih yang telah diusangkan tetapi masih mempunyai daya berkecambah tinggi mengindikasi benih tersebut mempunyai vigor tinggi.

\section{Kesimpulan}

Dengan pengusangan cepat secara fisik (suhu $41^{\circ} \mathrm{C}$ dan kelembaban tinggi $90 \%$ ) selama 72 jam dapat menurunkan viabilitas tetua benih padi hibrida. Selama pengusangan proses metabolisme benih berjalan dengan cepat sehingga viabilitas benih semakin menurun.

\section{Daftar Pustaka}

Blance, C. A., Elam, W. W. 1989. Accelerated Aging : A Potential Vigor Test for Multipurpose Tree Seeds. Proceeding Seed Conference. Mississipi State. USA.

Byrd, H. W. 1983. Pedoman Teknologi Benih (Terjemahan). Jakarta: Pembimbing Masa. $78 \mathrm{hlm}$

Copeland, L. O. 1976. Principles of Seeds Science and Technology. Burgess Pub. Com. Minneapolis. Minnesota. 369 p. ., McDonald, M. B. 1995. Principles of Seeds Science and Technology 3rd ed. New York. Chapman \& Hall. . 408 p.

McDonald, M. B. 2001. Principles of Seeds Science and Technology 4rd 4th editions. Kluwer Academic publishers London.

Heydecker, W. 1972. Vigour. P. 253-300. In E.H. Robert (ed) Viability of Seeds. New Fetterlane London. Chapman and Hall Ltd.

Ilyas, S. 1986. Pengaruh Faktor Induced dan Enforced Terhadap Vigor Benih Kedelai (Glycine max (L.) Merril) dan Pengaruhnya Terhadap Produksi Per Hektar [Tesis]. Bogor: Program Pascasarjana, Institut Pertanian Bogor. hlm
81.

Iqbal and shaazad, A. M., Basyra., Pur-rehman Khalil 2002. Evaluations of Vigor and Oil Quality in Cutten Seed during Accelerated agen. J. Agric. Biol. 48: 318-322.

ISTA. 2007. International Rules for Seed Testing, 2007 Edition. International Seed Testing Association, Zurich.

Justice, O. L., Bass, L. N. 1990. Prinsip dan Praktek Peyimpanan Benih. Terjemahan Jakarta.Rajawali Pers. 446 hlm.

Kalpana, R., Rao, K. V. M. 1996. Lipid Changes During Accelerated Aging of Seeds of Pigeonpea (Cajanus cajan (L.) Millsp.) Cultivars. Seed Sci. \& Technol 24: 475483.

Mavi, K., I. Demir. 2007. Controlled deterioration and accelerated aging tests predict relative seedling emergence potential of melon seed lots. Hort. Sci. 42:1431-1435.

Navaniratg, N. K. 2008. Performance of Scarisied and non scarisied. Of bixa orellana two Accelerated agents for the Prediction of Seed Science Accelerated J. Agric Biol. Sci. 4 : 591-595

Sadjad, S. 1980. Panduan Pembinaan Mutu Benih Tanaman Hutan. Kerjasama Proyek Pusat Perbenihan Kehutanan Direktorat Reboisasi dan Rehabilitasi Direktorat Jenderal Kehutanan dengan Kelembagaan Afiliasi IPB.300 hlm. 1984. Seed Storage and Storability. FAO/Austria Workshop 11 on Seed Testis for the Tropics. Tegalgondo. $24 \mathrm{p}$. 1993. Dari Benih kepada Benih. Jakarta. PT. Gramedia Widiasarana Indonesia. $144 \mathrm{hlm}$.

1994. Kuantifikasi Metabolisme Benih. Jakarta. PT. Gramedia Widiasarana Indonesia. $145 \mathrm{hlm}$.

Saenong. 1986. Pendugaan daya simpan benih kedelai (Glycine max L.). Tesis. Program Pascasarjana. Institut Pertanian Bogor. Bogor.

Steel, R. G. D., Torrie, J. H. 1993. Prinsip dan Prosedur Statistika. Terjemahan Sumantri B. Gramedia. Jakarta.

Tilabeni, G. H., Golpayegani, A. 2011. Effec of Seed Agant and phyciolocal and Bichemical Sanges Schanges in Rice Seed Oriza sativa ) int. J. Agric. Sci. Iran 1:138143. 